\title{
Domestic Plant Productivity and Incremental Spillovers from Foreign Direct Investment
}

\author{
Carlo Altomonte and Enrico Pennings
}

\begin{tabular}{|l|l|}
\hline \multicolumn{2}{|l|}{ ERIM REPORT SERIES RESEARCHINMANAGMENT } \\
\hline ERIM Report Series reference number & ERS-2009-012-STR \\
\hline Publication & March 2009 \\
\hline Number of pages & 29 \\
\hline Persistent paper URL & http://hdl.handle.net/1765/15143 \\
\hline Email address corresponding author & pennings@ese.eur.nl \\
\hline Address & Erasmus Research Institute of Management (ERIM) \\
& RSM Erasmus University / Erasmus School of Economics \\
& Erasmus Universiteit Rotterdam \\
& P.O.Box 1738 \\
& 3000 DR Rotterdam, The Netherlands \\
& Phone: $\quad+31104081182$ \\
& Fax: $\quad+31104089640$ \\
& Email: info@erim.eur.nl \\
& Internet: $\quad$ www.erim.eur.nl \\
\hline
\end{tabular}

Bibliographic data and classifications of all the ERIM reports are also available on the ERIM website: www.erim.eur.nl 


\section{ERASMUS RESEARCH INSTITUTE OF MANAGEMENT}

\section{REPORT SERIES}

\section{RESEARCH IN MANAGEMENT}

\begin{tabular}{|l|l|}
\hline ABSTRACT AND KEYWORDS \\
\hline Abstract & $\begin{array}{l}\text { We develop a simple test to assess whether horizontal spillover effects from multinational to } \\
\text { domestic firms are endogenous to the market structure generated by the incremental entry of the } \\
\text { same multinationals. In particular, we analyze the performance of a panel of 10,650 firms } \\
\text { operating in Romania in the period 1995-2001. Controlling for the simultaneity bias in } \\
\text { productivity estimates through semi-parametric techniques, we find that changes in domestic } \\
\text { firms' TFP are positively related to the first foreign investment in a specific industry and region, } \\
\text { but get significantly weaker and become negative as the number of multinationals that enter in } \\
\text { the considered industry/region crosses a specific threshold. These changing marginal effects } \\
\text { can explain the lack of horizontal spillovers arising in traditional model designs. We also find } \\
\text { these effects to vary between manufacturing and service, suggesting as a possible explanation a } \\
\text { strategic change in technology transfer decisions by multinational firms as the market structure } \\
\text { evolves. }\end{array}$ \\
\hline Free Keywords & multinational firms, productivity, transition economies \\
\hline Availability & $\begin{array}{l}\text { The ERIM Report Series is distributed through the following platforms: } \\
\text { Academic Repository at Erasmus University (DEAR), DEAR ERIM Series Portal } \\
\text { Social Science Research Network (SSRN), SSRN ERIM Series Webpage } \\
\text { Research Papers in Economics (REPEC), REPEC ERIM Series Webpage }\end{array}$ \\
\hline Classifications & $\begin{array}{l}\text { The electronic versions of the papers in the ERIM report Series contain bibliographic metadata } \\
\text { by the following classification systems: } \\
\text { Library of Congress Classification, (LCC) LCC Webpage } \\
\text { Journal of Economic Literature, (JEL), JEL Webpage } \\
\text { ACM Computing Classification System CCS Webpage } \\
\text { Inspec Classification scheme (ICS), ICS Webpage }\end{array}$ \\
\hline
\end{tabular}




\title{
Domestic plant productivity and incremental spillovers from foreign direct investment
}

\author{
Carlo Altomonte* $\quad$ Enrico Pennings ${ }^{\dagger \ddagger}$
}

First version: July 200\%; Revised version: February 2008

\begin{abstract}
We develop a simple test to assess whether horizontal spillover effects from multinational to domestic firms are endogenous to the market structure generated by the incremental entry of the same multinationals. In particular, we analyze the performance of a panel of 10,650 firms operating in Romania in the period 1995-2001. Controlling for the simultaneity bias in productivity estimates through semi-parametric techniques, we find that changes in domestic firms' TFP are positively related to the first foreign investment in a specific industry and region, but get significantly weaker and become negative as the number of multinationals that enter in the considered industry/region crosses a specific threshold. These changing marginal effects can explain the lack of horizontal spillovers arising in traditional model designs. We also find these effects to vary between manufacturing and services, suggesting as a possible explanation a strategic change in technology transfer decisions by multinational firms as the market structure evolves.
\end{abstract}

JEL classification: F23; L10; P20

Keywords: multinational firms, productivity, transition economies.

\footnotetext{
${ }^{*}$ Department of Institutional Analysis and Public Management - Bocconi University, Via Gobbi 5, 20136 Milano, Italy. Phone +3902 58365405. Fax +3902 58365439. carlo.altomonte@unibocconi.it

${ }^{\dagger}$ Erasmus University, Tinbergen Institute and ERIM, Rotterdam. Corresponding author: Faculty of Economics H13-31, Erasmus University Rotterdam, Burg. Oudlaan 50, 3062PA Rotterdam, Netherlands. Phone +31 10 4082166. Fax +31 10 4089149. pennings@few.eur.nl

${ }^{\ddagger}$ Acknowledgements: We wish to thank Rene Belderbos, Davide Castellani, Chiara Criscuolo, Johannes Moenius, Alberto Pozzolo, two anonymous referees and seminar participants at the 2005 CNR Workshop in International Economics (Urbino, Italy), the 32nd EARIE Conference (Porto), the 7th ETSG meeting (Dublin), the 3rd EIIE Conference (Koper, Slovenia), WIIW (Vienna) and CEPII (Paris) for helpful comments and suggestions. The usual disclaimer applies.
} 


\section{Introduction}

The debate on the existence of productivity spillovers from foreign direct investment (FDI), taking place through contacts between multinational (MNE) and domestic firms in a hot topic in the international business literature. The growing important role of international capital flows is also increasing the relevance of the debate in terms of policy implications: a confirming stance is often taken as a justification of expensive incentive packages for the attraction of foreign investors, while the evidence of negative effects is likely to nurture protectionist arguments. Observing the strong heterogeneity in motives, sources and timing of multinational entry, it is actually disputable if all foreign entry is equally beneficial for domestic firms' productivity. As a result, empirical studies have not come up with a clear answer to the question whether domestic firms benefit from foreign investors or not.

Given the potential heterogeneity of scenarios leading to a result of insignificant spillovers, the aim of this paper is to provide a more precise measurement of the timing and direction of the dynamic effects of MNEs' entrance. In particular, we develop a simple framework to test for the existence of a threshold number of foreign investors below which horizontal spillovers are positive, and above which there is a negative marginal effect on domestic TFP (or the other way round). If such a threshold exists for a positive number of multinational firms, we can conclude that the concept of 'marginal' spillovers becomes relevant, i.e. the combined effect of positive horizontal spillovers and competition from MNEs on domestic firms' TFP is not constant, but rather varying with the progressive entry of new MNEs. The direction of variation (from positive to negative or the other way round) is then assessed by looking at the signs of the coefficients.

The prediction of a non-constant marginal effect is tested on a rich panel dataset containing information on some 10,650 local and multinational firms in Romania, with balance sheet data available for the period 1995-2001, and firm-specific FDI data which start in 1990. As FDI was virtually prohibited before the fall of the Berlin Wall in 1989, the sample allows us to track MNEs from the very first investment on, thus taking into account potential first-mover effects. Anticipating our results, we find that in Romania a positive threshold number of MNEs exists, around which the impact on domestic firms' TFP changes from positive to negative, thus highlighting the relevance of marginal spillovers. Moreover, we also find marginal spillover effects to be industry-specific.

These results allow us to contribute to the analysis of MNEs' spillovers under a number of different perspectives. First of all, our findings contribute in explaining some of the reasons according to which traditional measures of horizontal spillovers identified by the international business literature tend to be not significant. Within the debate in the economics literature, we are also able to provide some methodological contributions to the traditional specification of a spillover regression: we control for and openly discuss a number of potential problems, among which a comparison of different TFP estimates employed to control for the simultaneity bias (Levinsohn and Petrin, 2003 vs. Olley and Pakes, 1996), and an analysis of the omitted price 
variable bias affecting the same estimates. In particular, the latter bias is assessed through a modified version of the Levinsohn-Petrin (2003) semiparametric algorithm of TFP estimation. Our results also allow us to shed new light on policy recommendations for attracting foreign investors. If marginal spillovers are relevant and, as it is the case for Romania, the effects on domestic firms are initially positive and then declining as more MNEs enter, then FDI attraction policies should focus on industries where there is no or little foreign presence, since in these sectors the positive spillover effect is likely to (still) outweigh the negative competition effect.

The rest of the paper is organized as follows. The next section provides some theoretical background on the spillover debate and presents our working hypotheses. Section 3 discusses the investment and TFP data employed in the analysis, while our methodology is discussed in section 4. Section 5 analyzes the empirical results, performs some robustness checks and presents some policy implications. Finally, section 6 concludes discussing the managerial and policy implications of our findings and providing some future lines of research.

\section{Theoretical background}

Pioneering empirical studies on sector-specific data (e.g. Caves, 1974) generally conclude that there are indeed positive productivity spillovers from FDI to domestic firms. Aitken and Harrison (1999) however criticize the methodology of the sectoral studies where positive spillovers were found, on the ground of an endogeneity problem. They argue that foreign investments primarily occur in sectors where domestic total factor productivity (TFP) is already high, thus leading to a critical identification problem. Using panel data on Venezuelan plants and controlling for fixed differences in productivity levels across industries, they find no significant intra-industry spillovers from foreign firms to domestic firms. Other studies with firm-level panel data also failed to identify positive spillovers from FDI, leading Gorg and Greenaway (2004), in their extensive survey of this literature, to point out the inconclusive evidence emerging from several empirical contributions on the issue ${ }^{1}$. More recently, Smarzynska Javorcik (2004), working on Lithuanian firm-specific data, has been the first to detect significant positive spillovers arising through backward linkages, i.e. generated through contacts between multinational affiliates and local input suppliers (vertical spillovers). She finds instead no clear evidence in favour of either intra-industry effects (horizontal spillovers), or forward linkages.

The finding of positive vertical spillovers and no, or even negative, horizontal ones is in general ascribed ex-post to the existence of "market-stealing" effects: in the product market, the domestic firm's sales could be squeezed by the entry of the foreign competitor, leading to a decrease in productivity if adjustment costs prevent inputs to be reduced accordingly or if

\footnotetext{
${ }^{1}$ For example, limiting our attention to transition economies, the studies of Djankov and Hoekman (2000) on the Czech Republic, and of Konings (2001) on Bulgaria, Poland and Romania, either fail to find a significant positive effect or even detect a negative impact that multinational corporations generate on the performance of domestic firms in the same sector. The situation is slightly different for developed countries, where some studies have found evidence of positive intra-industry spillovers (e.g., Haskel, Pereira and Slaughter, 2002, using UK plant level data).
} 
economies of scale are operating (Markusen and Venables, 1999); in the factor market, foreign firms may attract the higher-skilled workers at the detriment of domestic firms, since MNEs tend to pay higher wages (Aitken et al., 1996), thus providing another channel through which the entry of a foreign firm may negatively affect domestic TFP.

And yet, a precise assessment of these effects has not been thoroughly analyzed in the literature, due to the restrictive approach employed in the estimation of spillovers. In general horizontal spillovers are measured by regressing, within a panel structure, some indicator of productivity of domestic firms against an indicator of 'presence' of MNEs in the same industry². By looking at the average sign and significance of this coefficient across sectors and over time (if employing a panel dataset), inference is then made on the presence or not of horizontal spillovers and their impact on the performance of domestic firms. But a correct assessment of potential spillovers effects implies reckoning that the latter are ultimately driven by two sources of variation: the (sector-specific) effects of MNEs' entry across the observational units, and the change in the sign of these effects over time. In other words, the marginal impact of MNEs on the performance of domestic firms is not necessarily always positive or negative over time and across sectors.

In particular, in a recent contribution Buckley et al. (2007) have shown that, across sectors, there may exist an inverse u-shaped relationship between FDI and domestic productivity, so that beyond some level of foreign presence spillovers begin to fall ${ }^{3}$. In a related study, albeit through a different setup, Driffield and Love (2007) find a similar level of heterogeneity across industries, showing how different types of FDI in the United Kingdom have markedly different spillover effects, thus leading to insignificant results when these effects are pooled together. Although unable to test, the same Buckley et al. (2007) acknowledge that also the time dimension is relevant in assessing spillovers. For example, the first mover foreign investor might generate positive spillovers for the domestic firms, which are offset by further entry only at a later stage. On the contrary, the market-stealing effect might predominate once FDI start to flow in the host country, but, over time, the surviving local competitors might adapt their production processes to the changing market conditions, with their TFP actually increasing as more MNEs enter due to a selection effect. It can also happen that a larger number of MNEs magnifies the learning opportunities for domestic firms, thus resulting in a positive impact on TFP growth rates over time (Liu, 2006).

Finally, for the internalization of foreign knowledge, firms with a larger absorptive capacity can benefit more from foreign knowledge (Aitken and Harrison, 1999). Therefore, in industries where domestic firms possess more absorptive capacity, the positive effect of inward foreign

\footnotetext{
${ }^{2}$ In the 'horizontal' case, the most commonly used indicator of MNEs' presence is the share of MNE's employment over total employment within the considered industry. Such a practice might be itself subject to some criticism, as discussed in the next sections.

${ }^{3}$ The authors point to the fact that sectors in which there is a high level of foreign presence tend to be those in which Chinese firms are rather weak and have relatively low productivity. This causes the positive relation to weaken across sectors and eventually become negative.
} 
investment on productivity will be stronger.

Based upon the previous considerations, we thus test two hypotheses:

1. entry of foreign multinationals has a non-constant impact when examining domestic productivity in relation to the number of foreign multinationals that entered the domestic industry;

2. the impact of foreign entry is stronger in industries where firms are on average larger.

As discussed before, both hypotheses are tested within an empirical model that allows for a threshold number of foreign investments beyond which the impact on domestic productivity changes sign.

\section{The Romanian dataset}

Our dataset is composed of domestic firms and affiliates of multinational enterprises operating during the period 1995-2001 in Romania, as retrieved from AMADEUS. In the case of Romania, the dataset reports information retrieved by the Romanian Chamber of Commerce and Industry, the institution to which all firms have to be legally registered and report their balance sheet data. In particular, the 'intermediate' version of AMADEUS used in this paper includes data on 30,148 firms for Romania (2004 edition). See the Appendix for more information.

For every firm we have sought information on its location within each of the eight Romanian regions and the industry in which these firms operate (at the NACE-2 and 3 level, as reported in the Statistical Annex), as well as yearly balance sheet data on tangible and intangible fixed assets, total assets, number of employees, material costs and revenues (turnover). Moreover, we have gathered information on the year of incorporation in order to distinguish between firms which have always been operating in the considered time span and firms which have entered over the period, thus controlling for a possible sample selection bias resulting from unbalanced panel data, in line with the previous literature. Exiting firms are also considered, recording as exiters those firms which do not report any information after a given year. Finally, we have included in the sample only those firms for which detailed information on the ownership structure is available: in particular, we have considered a firm as foreign if more than 10 per cent of its capital belongs to a MNE, and domestic otherwise. However, we are not able to discriminate between different modes of foreign entry (acquisition vs. greenfield investment) ${ }^{4}$, motives for foreign entry (Driffield and Love, 2007), or FDI's country of origin (Buckley et al., 2002 and 2007).

Our final sample consists of a total of 10,650 employable firms, 30 per cent of which are MNEs in 2001, with entry and exit dynamics reported in Table 1 . The distribution over time and across

\footnotetext{
${ }^{4}$ Spatareanu and Smarzynska Javorcik (2006) examine on a sample of Romanian firms whether the degree of spillovers from foreign direct investment is affected by the foreign ownership modality and share in investment projects. We will discuss the issue of foreign ownership and its impact on our results in Section 5.
} 
industries of MNEs is reported in Table $2^{5}$. In terms of representativeness, we have retrieved from our sample a yearly measure of regional output, summing the individual firms' revenues operating in each region. We have then correlated these figures with the official regional figures for Romania, obtaining a significant positive correlation of $0.83^{6}$. As a result our firm-level data seem to belong to an unbiased sample, being able to reproduce the actual evolution of output in Romania.

[Table 1 and 2 about here]

\section{Methodology}

We have grouped the methodological issues related to the estimation of the relationship between the presence of MNEs and their impact on domestic firm's performance under three headings: the estimation of the dependent variable (TFP), the regressors to include in the spillover regression, and the model design. Our aim is to openly discuss all these issues, assessing their relevance through different model designs and a number of robustness checks, in order to derive a precise assessment of the impact they might have on the eventual detection of horizontal spillovers.

\subsection{The estimation of Total Factor Productivity}

In terms of calculation of domestic firm-specific productivity, we have initially followed the standard approach of deflating our balance sheet data using disaggregated industry price indexes. In particular, we have employed a total of 48 NACE2 or NACE3 industry-specific price indices retrieved from the Eurostat New Cronos database, according to the classification reported in the Statistical Annex ${ }^{7}$. We have proxied output with deflated sales, given the better quality of these time series with respect to the ones reporting value added. The number of employees has been used as a proxy for the labour input, and the deflated value of tangible fixed assets as a proxy for capital.

We have then estimated productivity measures at the firm level within each NACE2 industry, in order to correctly identify industry-specific technological coefficients and thus allowing us to correctly differentiate between manufacturing and services ${ }^{8}$. Moreover, the estimation has

\footnotetext{
${ }^{5}$ Information on the FDI stock up to 1994 has been retrieved from the PECODB dataset, a firm-specific collection of 4,200 FDI operations undertaken in the countries of Central and Eastern Europe in the period 19902002, also based on the intermediate version of AMADEUS (2003) and developed by ISLA-Bocconi University. In terms of validation, the database is able to account for almost 70 per cent of the region's total FDI inward stock in the early years of transition, as registered by official statistics.

${ }^{6}$ Since our sample does not include all NACE industries (in particular agriculture), we have subtracted from official regional GVA data the output of those industries not present in our dataset. The correlation between our sample and the official regional data comprising all NACE industries is instead 0.73.

${ }^{7}$ The classification is known as Pavitt classification and allows to divide industries into different technological patterns: economies of scale, traditional, high tech and specialised industries, plus services. The same grouping has been used by Davies and Lyons (1996) to divide industries into high, medium and low sunk costs. As such, the classification allows us to consider market structures, and hence prices, as relatively homogeneous within each industry.

${ }^{8}$ Imposing common input elasticities for firms belonging to different industries would in fact result in an
} 
been carried out via a semi-parametric estimation technique. In fact, using ordinary least squares when estimating productivity implies treating labor and other inputs as exogenous variables. However, as pointed out by Griliches and Mareisse (1995), profit-maximizing firms can immediately adjust their inputs (in particular capital) each time they observe a productivity shock, which makes input levels correlated with the same shocks. Since productivity shocks are unobserved to the econometrician, they enter in the error term of the regression. Hence, inputs turn out to be correlated with the error term of the regression, and OLS estimates of production functions suffer from the so-called simultaneity bias. Olley and Pakes (1996) and Levinsohn and Petrin (2003), henceforth OP and LP, have developed two similar semiparametric estimation procedures to overcome this problem using, respectively, investment and material costs as instruments for the unobservable productivity shocks.

Since both methodologies have been employed in the literature, and both present some shortcomings ${ }^{9}$, in principle it is correct to compute productivity through both approaches in order to test the robustness of the TFP estimates. As shown in Figure 1, the distribution of domestic firms' TFP as retrieved through both the LP (unrestricted sample) and OP (restricted sample, positive investments) algorithms tend to overlap over the entire sampling period, once normalizing the TFP of a given firm by the industry average (correlation of 0.8 , significantly different from zero at the 1 per cent level). Hence, any bias in the estimation of TFP eventually induced by the estimation technique can be ruled out, as long as our dependent variable is considered in first differences ${ }^{10}$.

[Table 3 and Figure 1 about here]

We have therefore opted to use the TFP estimates of individual domestic firms retrieved from the LP procedure, since the latter allows us to exploit all the data in our sample. Note also that we have run our estimates for domestic firms only, thus avoiding the possibility that the FDI status of a firm might have an effect on the choice of input factors, another potential source of bias in the estimates of productivity (Van Biesebroeck, 2005). Table 3 reports the obtained production function coefficients for a number of manufacturing and services industries. Not surprisingly, the latter display higher coefficients of the labour input, even after correcting

overestimation of productivity for firms operating in sectors which have higher returns. The shortcoming of an industry-specific estimation is that, in a few cases (i.e. NACE16, 20), the number of firm-level observations available for each industry has not allowed a proper identification of the input coefficients. Accordingly, TFP measures from firms belonging to these industries have not been considered in the follow-up of our exercise.

${ }^{9}$ The LP methodology has been criticized on the grounds that the conditional demand for materials itself depends on the productivity shock, and thus materials are not a valid instrument to solve the simultaneity bias. The OP methodology does not suffer from the latter shortcoming, since the investment function is entirely determined before the productivity shock takes places. However, a major assumption of the OP approach is the existence of a strictly monotonous relationship between the instrument (investment) and output. This means that any observation with zero or negative investment has to be dropped from the data, thus potentially inducing a selection bias in the TFP estimation.

${ }^{10}$ Taking the dependent variable (TFP) in first differences also allows to control for the unobserved firm-specific heterogeneity which may affect the correlation between firm productivity and foreign presence (e.g. Smarzynska Javorcik, 2004). 
for the simultaneity bias, since services are typically more labour intensive.

Another important source of distortion in the estimation of TFP, not yet fully tackled by the spillovers literature, relates to the so-called omitted price variable bias in the measurement of domestic firms' productivity. Since the seminal paper of Klette and Griliches (1996), it is known that proxying physical inputs and outputs through nominal variables deflated by a broad price index might lead to biased productivity measures, due to an omitted price variable bias induced by the correlation between (unobserved) individual firms' prices and their used inputs ${ }^{11}$. Such a bias can potentially affect the estimated TFP, and hence the spillover analysis, in various ways. On the one hand, inputs are positively correlated with the level of output, which is typically negatively correlated with prices. If individual firm prices remain in the error term due to improper deflating, then the error term and the inputs are positively correlated, which yields an underestimated coefficient of labor and materials and thus distorted TFP estimates. On the other hand, improper deflating leads to a measurement error in the output variable: if prices charged by domestic firms are below the industry average, e.g. because of lower quality with respect to MNEs, the latter distortion will induce a downward bias in the estimated firms-specific TFP, which in turn might lead to a spurious absence of horizontal spillovers ${ }^{12}$.

We assess these critiques in two ways: first of all, we follow Katayama, Lu and Tybout (2003), who argue that taking industry and region-specific averages on firm-specific TFP measures allows to partially counter the omitted price variable bias, since the cross-producer variation in productivity measures is much more problematic than the temporal variation of the population of plants. In addition, following the spirit of Klette and Griliches (1996), we control for the degree of imperfect competition on the demand side of the market allowing for spatial substitutability in demand (e.g. as in Syverson, 2005), assuming that deviations of domestic firms' prices of outputs and inputs (our measurement error) have a spatial component which can be controlled for. To this extent, we develop a slightly modified version of the original Levinsohn and Petrin (2003) algorithm, estimating an industry-specific production function augmented with regional fixedeffects, in order to pick up different pricing powers of domestic firms in the different Romanian regions.

\subsection{The measure of MNEs' presence}

In the traditional spillover regression, the presence of MNEs is measured through the ratio of multinational employees over total employment in the considered industry $z$, region $j$ and year $t$. A positive and significant coefficient for the variable related to MNE's presence in the industry

\footnotetext{
${ }^{11}$ Eslava et al. (2004) discuss this issue in their analysis of productivity of Colombian firms, where they can exploit the availability of firm-specific information on prices and quantities. DeLoecker (2007) provides a formal econometric discussion of the omitted price variable bias.

${ }^{12}$ Starting from firms' $i$ revenues $Y$ expressed as quantities time prices, and considering $P_{I}$ as the industry average price index, taking logs of the deflated revenue we have $y_{i}-P_{I}=q_{i}+p_{i}-P_{I}$. To the extent that some domestic firms price below the industry average, we have that $\left(p_{i}-P_{I}\right)<0$ and thus our observed deflated revenue $y_{i}-P_{I}$ is downward biased, leading to a similar bias in the TFP measure.
} 
is then interpreted as evidence of horizontal spillovers ${ }^{13}$. A lag structure imposed on the MNErelated variables allows to control for the potential endogeneity of the MNEs' presence in the selected region-industry pair.

A model design of this kind implies however that an equiproportional increase in the MNEs' employment and the total employment (thus yielding a constant share) will have no effect on domestic firms' productivity. But if the absolute values of the elasticities of foreign and total employment are different, Castellani and Zanfei (2006) have shown that using only the ratio of foreign to total employment downwardly biases the estimate of the coefficient, and might thus be responsible for the lack of evidence on horizontal spillovers. As a result, we have compared the standard model design, where spillovers are captured by the horizontal penetration index, with a model design where the presence of MNEs is identified by the number of the same multinationals operating in a given industry/region in a given year, controlling for the industry-specific average investment size.

Moreover, contrary to standard practice, we have opted not to time-difference the covariates related to the MNEs' presence. In fact, a difference in difference spillover regression imposes the assumption that changes in productivity of domestic firms are driven only by changes in the presence of MNEs, which is not necessarily true, since domestic firms might be affected differently by the same stock of MNEs over time via learning (e.g. Liu, 2006). We thus explicitly control for the learning hypothesis, by introducing in our regression the number of years since the first investment has taken place in a given industry/region.

\subsection{The spillover regression}

Our baseline model design is the standard spillover regression, relating domestic firms' TFP to the presence of MNEs in the industry-region pair (Model 1):

$$
\Delta \ln \left(T P F_{i t}\right)=\alpha+\beta H P_{z j t-1}+\gamma_{z}+\gamma_{j}+\gamma_{t}+\varepsilon_{i t}
$$

In Equation (1), $\Delta \ln \left(T P F_{i t}\right)$ is the change in the (log of) $T F P$ of firm $i$ at time $t$ and $H P_{z j t}$ is the index of horizontal penetration calculated as the ratio of multinational employees over total employment in the considered industry $z$, region $j$ and year $t$. As it is standard in the literature, a positive and significant $\beta$ would be interpreted as evidence of horizontal spillovers.

Such a specification typically allows to tackle a number of econometric concerns. First of all, as already discussed, the unobserved heterogeneity which may affect the correlation between firm productivity and foreign presence is controlled for by first differencing the (log of) TFP, i.e. using $\Delta \ln \left(T P F_{i t}\right)$ in order to wipe out unobserved firm-specific fixed effects, and by including industry, region and time fixed effects $\gamma_{z}, \gamma_{j}$ and $\gamma_{t}$, respectively. Lagging one period the MNEsrelated variables allows us to control for the potential endogeneity of the MNEs' presence in the

\footnotetext{
${ }^{13}$ Vertical spillovers would then be measured by weighting the horizontal penetration index with the inputoutput coefficients, as in Smarzynska Javorcik (2004).
} 
selected region-industry pair. Finally, since we perform a regression on micro units using mainly aggregate variables as covariates (at the regional and industry level) it is common practice to control for the potential downward bias in the estimated errors by clustering the standard errors for all firm-level observations belonging to the same region-industry pair.

As already stated, such a model design implies, however, that an equiproportional increase in MNEs' presence and total employment will have no effect on domestic firms' productivity, which might bias downwardly the estimate of the spillover coefficient. To counter this possible criticism, we compare the previous model with the following regression equation (Model 2):

$$
\Delta \ln \left(T P F_{i t}\right)=\alpha D_{z j t-1}+\beta D_{z j t-1} C u m F D I_{z j t-1}+\gamma_{z}+\gamma_{j}+\gamma_{t}+\varepsilon_{i t}
$$

where again $\Delta \ln \left(T P F_{i t}\right)$ is the change in the $(\log )$ of $T F P$ of firm $i$ at time $t, D_{z j t-1}$ is a dummy variable related to the change in the number of MNEs taking value 1 if an investment is undertaken in industry $z$ of region $j$ in year $t-1$, and $C u m F D I_{z j t-1}$ is the cumulated number (in logs) of foreign investments in industry $z$ of region $j$ at time $t-1$. The coefficient $\alpha$ thus captures the average effect of a change in the horizontal MNEs' presence, while the coefficient $\beta$, which refers to the interaction of the investment dummy $D_{z j t-1}$ with the cumulated number of FDI, captures the marginal effects on domestic firms' TFP. The implicit assumption in this model design is that we treat all foreign investments as equal, since no weights are assigned to the value of investments ${ }^{14}$. However, all econometric specifications are sector-specific, so that differences in the size of investment across sectors (which account for the largest part of variation in firms' values) are controlled for. In addition, we will provide a robustness check of our results controlling in what follows for the minimum efficient scale.

Given our equation (2), a positive horizontal spillover from MNEs entry on the average change in domestic productivity is obtained, in principle, when $\alpha+\beta C u m F D I_{z j t-1}>0^{15}$. The ratio $\frac{\hat{\alpha}}{\hat{\beta}}$ derived from our model design is then a useful statistic to test the relevance of a FDI threshold around which the marginal effect on domestic firms' TFP change sign. In particular, the critical value of the number of foreign investors that determines the sign of the aggregate spillover can be calculated setting $\alpha+\beta C u m F D I_{z j t-1}=0$. E.g., if $\alpha>0, \beta<0$ and $-\frac{\alpha}{\beta}$ is significantly different from 0 , there exists a threshold value $C u m F D I^{*}=-\frac{\alpha}{\beta}$ of FDI below which aggregate spillovers are positive. Spillovers then become negative as soon as MNEs' entry crosses the threshold.

As already hinted, an econometric concern in the previous specification is related to the nature of CumFDI, a count variable which in principle treats as equal FDI in different industries, i.e. MNEs which are likely to be characterized by different firms' sizes. If there is a systematic

\footnotetext{
${ }^{14}$ The average capital of foreign firms (proxied by total fixed assets) in our sample is around 2 million euros, but with a large standard deviation. The same is true for employment (average of 259 employees). Also note that, given our sector classification, we have excluded from our sample all foreign affiiliates acting only as promotion agencies or sales representatives.

${ }^{15}$ Note that when assessing the overall impact of spillover as $\alpha+\beta C u m F D I_{i j t-1}$, the coefficient $\alpha$ can be interpreted as the effect of the first investment on domestic firms' TFP changes.
} 
difference over time in the size of MNEs which enter in each industry, ignoring it might lead to potential spurious correlations, not entirely captured by our fixed-effects. However, having calculated the median size of the MNEs that have entered in each industry in each year, we can rule out specific trends over time in this variable, and thus we conjecture that our results are not driven by particular dynamics of specific industries. Finally, the cumulated number of foreign investments is a variable increasing over time, and hence non-stationary. Although the variable enters in our specification always interacted with the investment dummy and time-effects are included in our regression, we could still get a positive spurious relation between TFP and foreign presence, as well as problems with the asymptotic properties of our estimators, if there is serial correlation in the error terms. Though the econometric literature in general acknowledges (e.g. Baltagi, 2001) that the problem is negligible in micro panels such as ours, characterized by a large number of cross-sectional units ( $48 * 8$ in our case) with respect to time (6 years), we report the modified version of the Durbin-Watson statistic for balanced panels, as proposed by Bhargava et al. (1982), in order to assess the extent of the problem for each model specification.

To counter the omitted price variable bias and measure the impact of the MNEs' presence on the average domestic firm, we have introduced a third model design (equation 3), aggregating firm-specific TFP measures across the 48 industries and 8 regions over the years 1995-2001, thus using as a dependent variable the average TFP of industry $z$ and region $j$ at time $t$ calculated over individual firms

$$
\Delta \ln \left(\overline{T P F}_{z j t}\right)=\alpha D_{z j t-1}+\beta D_{z j t-1} C u m F D I_{z j t-1}+\gamma_{z}+\gamma_{j}+\gamma_{t}+\varepsilon_{z j t}
$$

where $\Delta \ln \left(\overline{T P F}_{z j t}\right)$ is the average change of $(\log )$ domestic firms' TFP in industry $z$ and region $j$ in year $t$. As we have argued, the latter treatment of the dependent variable yields us a balanced panel across industries, regions and years, and allows us to minimize potential biases in our TFP measure deriving from the heterogeneity in the mark-ups faced by individual firms.

As a further refinement, we have specified an industry-specific threshold $C u m F D I_{z}^{*}$, in line with earlier studies suggesting industry-specific spillover effects (Liu et al., 2000) and spillover effects that are moderated by a measure of absorptive capacity (Sinani and Meyer, 2004). Moreover, as already discussed, a shortcoming of the previous specifications is that FDI undertaken in industries characterized by different average firm sizes, and thus different barriers to entry, are treated as equal. We have thus refined our model specification so that the threshold depends on $M E S_{z}$, the minimum efficient scale ${ }^{16}$ of industry $z$, as follows (Model 4):

$$
\Delta \ln \left(\overline{T P F}_{z j t}\right)=\alpha D_{z j t-1}+\beta D_{z j t-1} \frac{C u m F D I_{z j t-1}}{M E S_{z}}+\gamma_{z}+\gamma_{j}+\gamma_{t}+\varepsilon_{z j t}
$$

Interacting CumFDI and MES in the proposed way essentially implies to assign greater weight to those FDI undertaken in industries characterized by lower barriers of entry (lower

\footnotetext{
${ }^{16}$ The minimum efficient scale has been calculated as the median employment of the firms in each industry.
} 
$M E S)$. We can therefore control for the industries in which the competition effect from MNEs should be a priori stronger. Moreover, in the already quoted paper by Aitken and Harrison (1999), it is claimed that one should distinguish between large and small domestic firms, since it is more likely that industries characterized by larger firms will possess a sufficient level of absorptive capacity to benefit from the presence of FDI. The intuition explored in equation (4) is that industries characterized by larger firms (i.e. a higher MES) should exhibit a higher critical threshold level of FDI after which their spillover becomes negative. Interacting CumFDI and $M E S$ as reported yields in fact a critical value of the (industry-specific) threshold $C u m F D I_{z}^{*}=$ $-\frac{\alpha}{\beta} M E S_{z}$.

Finally, to include an intercept in the latter linear relationship for the threshold, we can generalize the model design as (Model 5)

$$
\Delta \ln \left(\overline{T P F}_{z j t}\right)=\alpha D_{z j t-1}+\beta D_{z j t-1} \frac{C u m F D I_{z j t-1}}{M E S_{z}}+\gamma D_{z j t-1} \frac{1}{M E S_{z}}+\gamma_{z}+\gamma_{j}+\gamma_{t}+\varepsilon_{z j t}
$$

so that the threshold becomes $C u m F D I_{z}^{*}=-\frac{\alpha}{\beta} M E S_{z}-\frac{\gamma}{\beta}$. In this case, we can then explicitly design a test statistic for both the coefficient of our functional form, $\frac{\alpha}{\beta}$, and its intercept $\frac{\gamma}{\beta} 17$.

The next section discusses the results of the various model specifications plus some additional control variables.

\section{Empirical results and robustness}

Our baseline results are presented in Table 4. In the first column we test the benchmark model of horizontal spillovers to domestic firms using firm-specific productivity measures (Model 1). In line with the recent literature, we do not find significant effects ${ }^{18}$. In column 2 we test for the existence of a possible FDI threshold (Model 2), always using domestic firm-specific productivity measures: we find a negative and significant (at 10 per cent) sign of the interaction between $D_{z j t-1}$ and CumFDI, thus indicating that the effects on domestic firms' productivity tend to change as the number of multinational increases. The critical value for the existence of the FDI threshold, $-\frac{\alpha}{\beta}$, is positive but not significantly different from 0 . To assess whether our results are to a certain extent driven by a possible omitted price variable bias, in columns 3 and 4 we test again the two models, this time using the average productivity changes $\Delta \ln \left(\overline{T P F}_{z j t}\right)$ as our dependent variable (Model 3). Again, we find positive but not significant horizontal spillovers when tested through the standard specification (column 3), but significant threshold effects (column 4). Having controlled for all other potential biases, the latter result might thus explain the lack of significance of horizontal spillovers when tested through traditional model

\footnotetext{
${ }^{17}$ Since the restrictions to test are non-linear, the test is based on a Wald statistic $\left(\chi^{2}\right.$-distributed) constructed through the estimated covariance matrix obtained from the unrestricted (linear) models (Greene, 2003, p. 176).

${ }^{18}$ We have also tested for backward and forward linkages, as in Smarzynska Javorcik (2004), finding weak evidence of vertical spillovers.
} 
designs.

[Table 4 about here]

In Table 5 we further explore this finding through our refined model designs explicitly testing for the existence of the FDI threshold. For a matter of comparison, column 1 replicates the last column of Table 4. As already discussed, we find that FDI undertaken at time $t-1$ has a positive and significant impact on the average productivity changes in a given industry/region, providing evidence of positive horizontal spillovers. More specifically, the estimate for $\alpha$ reveals that, on average, the first foreign investment in a specific sector and region increases domestic TFP by almost $3.5 \%$. The effect however decreases as the number of foreign investment inflows increases (negative sign of the interaction between $D_{z j t-1}$ and $C u m F D I$ ). The critical value, $-\frac{\alpha}{\beta}$, is positive and significantly different from 0 at the $5 \%$ level of significance. In particular, the threshold indicates that negative spillovers arise on average from the 12th investment on. The modified Durbin-Watson statistic is very close to 2 across all model specifications, indicating no problems of serial correlation in the error terms.

Nevertheless, in the previous model specification the estimate for $\beta$ is not significantly different from 0 , probably due to the industry-specific nature of $\beta$. In fact, interacting the cumulated number of FDI with the inverse of minimum efficient scale, calculated as the firms' median employment in each industry, highly reduces the industry heterogeneity and yields significant results, thus confirming our hypothesis (Model 4) of the existence of an industry-specific threshold CumFDI $I_{z}^{*}=-\frac{\alpha}{\beta} M E S_{z}$. Column 2 of the Table shows that $\alpha$ is still positive and significant, while $\beta$ is now also significantly different from 0 . Not surprisingly, our test statistic for the threshold $-\frac{\alpha}{\beta}$ remains positive and significant.

In order to check whether in our expression for the industry-specific threshold we have omitted an intercept term, we have also included in the regression the term $\gamma D_{z j t-1 \frac{1}{M E S_{z}}}$, which implies a threshold $C u m F D I_{z}^{*}=-\frac{\alpha}{\beta} M E S_{z}-\frac{\gamma}{\beta}$ (Model 5). To avoid multicollinearity, we have instrumented $\frac{1}{M E S_{z}}$, the (inverse of) the industry-specific MES, with $\frac{1}{M E S_{z j}}$, i.e. the (inverse of) MES calculated for each industry $z$ and region $j$. The results are reported in column 3. Again, both $\alpha$ and $\beta$ are significant, as it is our test statistic $-\frac{\alpha}{\beta}>0$, thus indicating the presence of a threshold effect. We cannot instead reject the hypothesis that the intercept, $-\frac{\gamma}{\beta}$, equals zero at conventional levels of significance.

[Table 5 about here]

In column 4 we explicitly test for the 'learning' hypothesis as discussed by Liu (2006), introducing in our benchmark model of the FDI threshold a variable $T$ measuring the (log) number of years since the first foreign investment took place in a given industry/region. The latter allows us to counter a possible omitted variable bias arising from the fact that, if the investment dummy $D_{z j t-1}$ is zero in our specification, the change in productivity of our domestic firm would not be a function of previous investment. As it can be seen, the variable is significant 
and negatively signed, while the estimates of $\alpha$ and $\beta$ do not change, as well as the significance of our test statistic for the threshold $-\frac{\alpha}{\beta}>0$. Hence, ceteris paribus domestic firms seem to experience a marginally decreasing change in productivity as time from the first investment goes by, consistent with the findings of Griffith et al. (2002) who found that there might be a convergence in total factor productivity of domestic firms towards the foreign ones, with the rate of productivity growth decreasing over time as more MNEs enter in the local market.

Finally, in column 5 we test whether spillovers vary between the manufacturing and services sector. In our sample, services constitute around $13 \%$ of our observations (see the Statistical Annex for a list of industries, including services). To that extent, we introduce a dummy $S E R V$ taking value one if the considered industry belongs to the services sector, and interact the dummy with the variables driving the threshold.

While the main effects remain unchanged for the manufacturing sector, including the significance of our test statistic for the threshold, the effects for services are different. In particular, in services the positive impact of the first investment on domestic firms remains positive but is diminished by 3.8 percentage points, while the negative effect induced by the increasing presence of MNEs is increased by some 39 percentage points, thus turning positive. Thus, the estimated coefficients for $\alpha$ and $\beta$ are both positive in the case of services, but not significantly different from zero ${ }^{19}$. We also find that the FDI threshold $-\frac{\alpha}{\beta}$ is not significantly different from zero for the services sector, implying that the main results we found are driven by the behavior of spillover in manufacturing industries.

Our interpretation of these results is that, overall, there seems to exist a general pattern of spillovers from FDI where productivity is boosted in the year immediately after the investment has taken place (positive $\alpha$ ), but then gradually decreases through both the changes in market structure (negative $\beta$ ), and the convergence to the frontier of domestic firms, which seem to learn marginally less as time goes by (as in Griffith et al., 2002). The results are however different in the services sector, leading to no FDI threshold in these industries ${ }^{20}$.

Table 6 presents a number of additional robustness checks of our findings, always controlling for the number of years since the first foreign investment took place in a given industry/region to avoid a possible omitted variable bias. In column 1, we specifically control for the actual number of foreign firms entering in a given sector/region and year, since it may be the case that multiple entries in a given year would affect differently the performance of domestic firms with respect to the case of a single FDI. Our variable $I N V_{z j t-1}$ measures the total number of foreign investment undertaken in industry $z$ of region $j$ in year $t-1$ (taken as the log of 1 plus the number of foreign investments). We maintain the interaction with our measure of FDI stock

\footnotetext{
${ }^{19}$ Denoting $\alpha_{S}$ and $\beta_{S}$ the coefficients for $D_{z j t-1} * S e r v$ and $D_{z j t-1} \frac{C u m F D I_{z j t-1}}{M E S} *$ Serv respectively, the Chi-sq. and p-values of the test Ho: $\alpha+\alpha_{S}=0$ and Ho: $\beta+\beta_{S}=0$ are $0.03(.85)$ and $0.02(.88)$, as retrieved from Column 5 of Table 5 .

${ }^{20}$ Albeit not significant, the combined effects of our estimates for $\alpha$ and $\beta$ in services would point in the direction of positive spillovers, consistent with the findings of Vahter and Masso (2007), who, using a similar semi-parametric measure of TFP, find some evidence of higher spillovers in services industry with respect to manufacturing in Estonia.
} 
CumFDI, in order to keep the same interpretation of the threshold value, and we always control for the average investment size $M E S$. The results are unchanged, with the value of our test statistic for the threshold more than doubled.

Following the related literature (e.g. Sinani and Meyer, 2004), as a further robustness check we have augmented our benchmark specification with the Herfindahl index calculated for both domestic and foreign firms (column 2a) or for domestic firms only (column 2b). We have also included a proxy for domestic firms' absorptive capacity, measured as the average investment in intangible assets over total assets in a given industry/region, and introduced a control for the stock of FDI cumulated at the beginning of our observation period (column 3). We do not find significant effects of the Herfindahl index or the initial FDI stock on the domestic firms' average TFP, while the absorptive capacity index is positive and significant, in line with other results obtained in the literature (e.g. Damijan et al., 2003) ${ }^{21}$. As it can be seen, our estimates of $\alpha$ and $\beta$ are very robust to these different model specifications, as well as our hypothesis of a zero intercept term in our threshold expression.

Finally, as a further robustness check, we have recalculated our estimates using a different measure of domestic firms' TFP, and namely the one retrieved by estimating an industry-specific production function augmented with regional fixed-effects, in order to pick up different pricing powers of domestic firms in the different Romanian regions. The results, presented in column 4 , show that the threshold $-\frac{\alpha}{\beta}$ remains significantly different from zero.

Unfortunately, our data do not allow us to perform a robustness check of the threshold effect with respect to a change in our definition of foreign ownership (10 per cent of capital stock, following the official IMF definition of foreign investment, as it is common in most studies). Nevertheless, we can draw on results from Spatareanu and Smarzynska Javorcik (2006), who, on a similar sample of Romanian firms from 1998 to 2000, show that positive horizontal spillovers are likely to increase with the percentage of foreign ownership. Hence, we expect the threshold to increase when a more restrictive definition of foreign ownership (i.e. majority or wholly-owned investment) is considered.

[Table 6 about here]

Reinterpreting our exercise in a policy perspective, we have exploited the estimates of $\alpha$ and $\beta$ reported in column 2 of Table 5 to calculate the FDI thresholds. Given the model design, the results, reported in Table 7, present the industry-specific thresholds of FDI for the average region. For example, Table 2 shows that the cumulated FDI in the pharmaceutical industry (NACE 243-245) equals to 35 investments for the entire country. Since this figure is lower than the average region-specific threshold retrieved in Table 7 (56), the pharmaceutical industry

\footnotetext{
${ }^{21}$ The industry average proxy for absorptive capacity ranges across domestic firms in our sample from 0.1 per cent (car production) to 6.9 per cent (computer industry).
} 
appears to be a sector where domestic firms can still benefit from inward FDI.

[Table 7 about here]

Table 7 also allows us to characterize industries according to their desiderability in terms of spillovers potential. Recalling the Pavitt classification of industries reported in the Statistical Annex, it is possible to calculate common thresholds for the different industrial groups by taking averages of the relevant industries. In particular, we obtain that policy makers should try to attract FDI in industries characterized by economies of scale, since the latter have the highest FDI treshold, 25 investments for the average region. On the contrary, traditional, labourintensive manufacturing industries have the lowest threshold $(3)^{22}$. Quite surprisingly, high-tech industries do not display a particularly high threshold, and thus do not seem particularly suited to generating sustained spillovers for the receiving country/region. We discuss our intuition for the latter result in our concluding remarks.

\section{Managerial implications and further lines of research}

Our analysis confirms that, in the case of Romania, there exists a (industry-specific) threshold of MNEs driving the results of aggregate spillovers. We can thus conclude that the concept of 'marginal' spillovers becomes relevant, i.e. the combined effects of positive horizontal spillover and competition on domestic firms' TFP are not constant, but rather varying with the progressive entry of new MNEs, with initially positive effects turning negative with the increase in the presence of multinationals. As a result, if horizontal spillovers measures are combined in a single coefficient, measuring the average impact over time of the MNEs' presence on the productivity of domestic firms, as the current literature has been doing, it is likely that the same coefficient is not significant, since the model design fails to take into account the changes in the market structure induced by the continuous entry of MNEs.

In terms of managerial implications, our results do not exclude that the presence of MNEs can prima facie benefit domestic firms. Actually, we do find a spillover effect for the initial investments in a given region / industry. However, we also provide robust evidence that, after a given threshold in the FDI presence, the spillover effect is outweighed by a marginally decreasing role of learning, as domestic firms convergence to the technology frontier (e.g. Griffith et al., 2002), and by a negative competition effect. As far as the latter is concerned, the negative impact of an increasing MNEs' presence on domestic firms' productivity can be consistent with the traditional market-stealing effect identified by the international business literature (e.g. Buckley et al., 2007). In fact, if we assume that foreign entry crowds out market shares of domestic firms, the latter would experience a reduction of their economies of scale, and thus of

\footnotetext{
${ }^{22}$ Consistently with our previous results, the threshold for services as retrieved from Column 5 of Table 5 turns out to be negative and not significantly different from zero.
} 
their TFP, with the effect becoming immediately evident in industries were economies of scale are relatively low. Consistently, we have indeed found that industries relatively more characterized by economies of scale display the highest FDI threshold. Scale and market stealing effects are known to be different in the services sector (Capar and Kotabe, 2003), and can thus also justify the different results we obtain for services industries vs. manufacturing ones.

However, our results also point to a different channel driving negative spillovers, more directly related to the strategic choices in the international allocation of (tangible and intangible) assets by MNEs. In fact, what remains to be explained is the quite surprising result of a low FDI threshold in industries characterized by a certain degree of R\&D intensity. A possible explanation involves strategic decisions of technology transfers by MNEs which enter the domestic market. In Blalock and Gertler (2007) it is indeed shown that MNEs might initially have an incentive to diffuse technology to their suppliers in order to avoid a hold-up problem. However, since the MNE cannot prevent the upstream suppliers from selling also to the multinational's competitors in the downstream market, too much competition might induce the same MNE to strategically reduce its degree of technology transfers. Belderbos et al. (2005) also find that the decision to invest in R\&D in a foreign country by a MNE affects negatively the location decision of similar activities by a rival MNE. Cantwell and Santangelo (2002) provide some empirical evidence consistent with this behaviour, since they find that MNEs operating in the same (electronics) industry tend to separate geographically their co-specialised research, while inter-industry cooperation entails the co-location of related research. Finally, Alcacer and Chung (2007) find that, while less technologically advanced firms favor locations with high levels of industrial innovative activity, technologically advanced firms choose only locations with high levels of academic activity and avoid locations with industrial activity to distance themselves from competitors.

Nesting these results into ours, we could therefore claim that the decrease in the importance of horizontal spillovers associated with an increasing presence of MNEs might derive also from a technological channel, since our results are consistent with strategic choices of MNEs in which the technological transfer is interrupted after a certain number of rivals' entries.

In terms of policy implications, the study therefore suggests that FDI attraction policies should focus on sectors where the marginal effect of foreign entry is positive, typically industries characterized by high economies of scale, as from our Table 7 for Romania. In sectors where the number of cumulated FDI is still below the calculated threshold, the spillover effect is likely to outweigh the competition effect and benefits for the productivity of local firms might be expected. In industries characterized by lower critical FDI thresholds, instead, any new FDI entering the market risks aggravating negative spillovers to domestic firms. Moreover, if we acknowledge that negative spillovers might also derive from strategic choices of MNEs linked to the risk of knowledge appropriation by rivals, adequate and effective policies protecting intellectual property rights might also play a significant role in magnifying positive spillovers for domestic firms. 
Clearly, while all these explanations are ex post consistent with our results, a thorough examination of these possible channels leading to differentiated spillover effects is left to a future research agenda. 


\section{References}

Aitken, B.J., A.E. Harrison and R. Lipsey (1996), Wages and Foreign Ownership. A Comparative Study of Mexico, Venezuela and the United States, Journal of International Economics 40: 345-371.

Aitken, B.J. and A.E. Harrison (1999), Do Domestic Firms Benefit from Direct Foreign Investment? Evidence from Venezuela, American Economic Review 89: 605-618.

Alcàcer, J. and Chung, W. (2007), Location Strategies and Knowledge Spillovers, Management Science 53: 760-776.

Arnold, J. and B. Smarzynska Javorcik (2005), Gifted Kids or Pushy Parents? Foreign Acquisitions and Plant Performance in Indonesia, CEPR DP No. 5065, London.

Baltagi, B.H. (2001), Econometric Analysis of Panel Data, Wiley, New York.

Bhargava, A., L. Franzini and W. Narendranathan (1982), Serial correlation and the fixed effects model, The Review of Economic Studies 49: 533-549.

Belderbos, R., E. Lykogianni and R. Veugelers (2005), Strategic R\&D Location by Multinational Firms: Spillovers, Technology Sourcing and Competition, CEPR DP No. 5060, London.

Blalock, G. and P. Gertler (2007), Welfare Gains from Foreign Direct Investment through Technology Transfer to Local Suppliers, Journal of International Economics, forthcoming.

Buckley, J., Clegg, J. and Wang, C.(2002), The Impact of Inward FDI on the Performance of Chinese Manufacturing Firms, Journal of International Business Studies 33: 637-655.

Buckley, J., Clegg, J. and Wang, C.(2007), Is the Relationship between Inward FDI and Spillover Effects Linear? An Empirical Examination of the Case of China, Journal of International Business Studies 38: 447-459.

Cantwell, J.A. and G.D. Santangelo (2002), The new geography of corporate research in information and communications technology (ICT), Journal of Evolutionary Economics 12: 163-197.

Capar, N. and M. Kotabe (2003), The Relationship between International Diversification and Performance in Service Firms, Journal of International Business Studies 34: 345-355.

Castellani, D. and A. Zanfei (2006), Multinational Firms, Innovation and Productivity, Chelthenam: Edward Elgar.

Caves, R.E. (1974), International Corporations: The Industrial Economics of Foreign Investment, Economica 38: $1-27$.

Damijan, J., B. Majcen, M. Knell and M. Rojec (2003), The Role of FDI, Absorptive Capacity and Trade in Transferring Technology to Transition Countries: Evidence from Firm Panel Data for Eight Transition Countries, Economic Systems 27: 189-204.

Davies, S. and B. Lyons (1996), Industrial Organization in the European Union, London: Clarendon Press.

De Loecker, J. (2007), Product Differentiation, Multi-Product Firms and Structural Estimation of Productivity, NYU Stern, mimeo.

Djankov, S. and B. Hoekman (2000), Foreign Investment and Productivity Growth in Czech Enterprises, World Bank Economic Review 14: 49-64.

Driffield, N. and J.H. Love (2007), Linking FDI Motivation and Host Economy Productivity Effects: Conceptual and Empirical Analysis, Journal of International Business Studies 38: 460-473. 
Eslava, M., J. Haltiwanger, A. Kugler and M. Kugler (2004), The effects of structural reforms on productivity and profitability enhancing reallocation: evidence from Colombia, Journal of Development Economics 75: 333-371.

Gorg, H. and D. Greenaway (2004), Much Ado about nothing? Do domestic firms really benefit from foreign investment?, World Bank Research Observer 19: 171-197.

Greene, W. (2003). Econometric Analysis, 5th Ed., Englewood Cliffs: Prentice Hall.

Griffith, R., S. Redding and H. Simpson (2002), Productivity Convergence and Foreign Ownership at the Establishment Level, CEPR DP No. 3765, London.

Griliches, Z. and J. Mairesse (1995), Production Functions: the Search for Identification, NBER WP No. 5067, Washington, D.C.

Haskel, J., S. Pereira and M.J. Slaughter (2002), Does Inward Foreign Direct Investment boost the Productivity of Domestic Firms?, NBER WP No. 8013, Washington D.C.

Katayama, H. S. Lu and J.R. Tybout (2003), Why Plant-Level Productivity Studies Are Often Misleading, and an Alternative Approach to Inference", NBER WP No. 9617, Washington D.C.

Klette, T.J. and Z. Griliches (1996), The Inconsistency of Common Scale Estimators when Output Prices Are Unobserved and Endogenous, Journal of Applied Econometrics 11: 343-361.

Konings, J. (2001), The Effect of Direct Foreign Investment on Domestic Firms: Evidence from Firm Level Panel Data in Emerging Economies, Economics of Transition 9: 619-633.

Levinsohn, J. and A. Petrin (2003), Estimating production functions using inputs to control for unobservables, Review of Economic Studies 70: 317-342.

Liu, X., P. Siler, C. Wang and Y. Wei (2000), Productivity Spillovers from Foreign Direct Investment: Evidence from UK Industry Level Panel Data, Journal of International Business Studies 31: 407-425.

Liu, Z. (2006), Foreign direct investment and technology spillovers: Theory and evidence, Journal of Development Economics, forthcoming.

Markusen, J. and Venables, A. (1999), Foreign direct investment as a catalyst for industrial development, European Economic Review 43: 335-356.

Olley, S. and A. Pakes (1996), The dynamics of productivity in the telecommunications equipment industry, Econometrica 64: 1263-98.

Sinani, E. and K.E. Meyer (2004), Spillovers of technology transfer from FDI: the case of Estonia, Journal of Comparative Economics 32: 445-466.

Smarzynska Javorcik, B. (2004), Does Foreign Direct Investment Increase the Productivity of Domestic Firms? In Search of Spillovers through Backward Linkages, American Economic Review 94: 605-627.

Spatareanu, M. and Smarzynska Javorcik, B. (2006), To share or not to share: Does local participation matter for spillovers from foreign direct investment?, Journal of Development Economics, forthcoming.

Syverson, C. (2005), Market Structure and Productivity: A Concrete Example, Journal of Political Economy 112: 1181-1222.

Vahter, P. and Masso, J. (2007), Home versus Host Country Effects of FDI: Searching for New Evidence of Productivity Spillovers, Applied Economics Quarterly 53: 165-196.

Van Biesebroeck, J. (2005), Exporting Raises Productivity in sub-Saharan African Manufacturing Firms, Journal of International Economics 67: 373-391. 
Table 1. The evolution of the panel of Romanian firms. Sample vs. official data

\begin{tabular}{|c|ccc|c|cc|cc|}
\hline Year & \multicolumn{3}{|c|}{ Number of firms } & \multicolumn{2}{c|}{ MNEs } & \multicolumn{2}{c|}{ Entry Rate } & \multicolumn{2}{c|}{ Exit Rate } \\
& Dom & MNEs & Total & penetration & Sample & Official & Sample & Official \\
\hline 1995 & 4764 & 1217 & 5981 & 0.20 & & & & \\
1996 & 5449 & 1504 & 6953 & 0.22 & 0.19 & 0.11 & 0.01 & 0.09 \\
1997 & 5898 & 1653 & 7551 & 0.22 & 0.11 & 0.08 & 0.01 & 0.07 \\
1998 & 6389 & 1896 & 8285 & 0.23 & 0.10 & 0.07 & 0.01 & 0.07 \\
1999 & 6957 & 2121 & 9078 & 0.23 & 0.10 & 0.06 & 0.01 & 0.06 \\
2000 & 7331 & 2603 & 9934 & 0.26 & 0.10 & 0.06 & 0.00 & 0.09 \\
2001 & 7605 & 3045 & 10650 & 0.29 & 0.08 & 0.11 & 0.02 & 0.10 \\
\hline
\end{tabular}

Source: authors' elaboration on the basis of AMADEUS dataset and Romanian Chamber of Commerce for official data.

Figure 1. Distribution of estimated domestic firms' productivity: O-P vs. L-P ${ }^{\text {a }}$

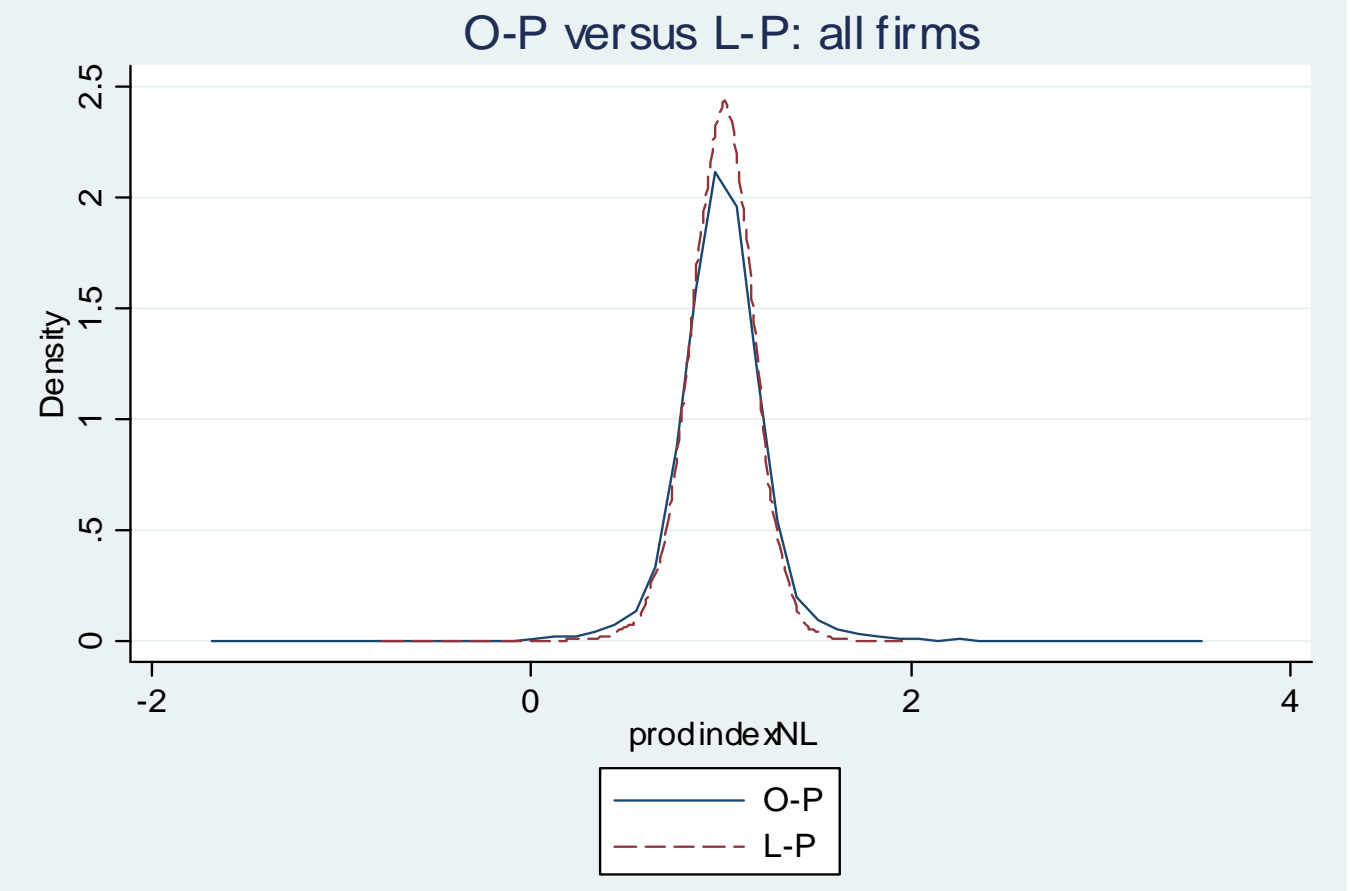

Note: TFP index of individual domestic firms for the period 1995-2001, normalized to industry average in a given year. O-P estimates are performed on the restricted sample (only domestic firms displaying positive investments), while the LP estimates are performed over the entire sample for the corresponding industries. 
Table 2. Cumulative FDI in Romania, 1990-2001.

\begin{tabular}{|c|c|c|c|c|c|c|c|c|}
\hline NACE & Stock 1994 & 1995 & 1996 & 1997 & 1998 & 1999 & 2000 & 2001 \\
\hline 10,14 & 2 & 13 & 24 & 31 & 36 & 42 & 48 & 49 \\
\hline 151,152 & 0 & 6 & 11 & 19 & 21 & 24 & 27 & 29 \\
\hline 153,155 & 0 & 10 & 17 & 26 & 30 & 39 & 44 & 49 \\
\hline 156 & 0 & 4 & 12 & 19 & 20 & 21 & 21 & 30 \\
\hline 157 & 0 & 0 & 0 & 1 & 2 & 3 & 4 & 4 \\
\hline 158 & 0 & 27 & 42 & 61 & 87 & 94 & 106 & 112 \\
\hline 159 & 6 & 10 & 21 & 24 & 32 & 35 & 39 & 40 \\
\hline 16 & 0 & 0 & 1 & 2 & 5 & 6 & 7 & 7 \\
\hline 17 & 1 & 9 & 28 & 54 & 77 & 97 & 109 & 124 \\
\hline 18 & 4 & 17 & 49 & 80 & 122 & 153 & 180 & 204 \\
\hline 19 & 0 & 9 & 22 & 39 & 57 & 66 & 83 & 97 \\
\hline 20 & 1 & 17 & 43 & 80 & 113 & 142 & 172 & 192 \\
\hline 21 & 0 & 3 & 11 & 14 & 22 & 27 & 33 & 34 \\
\hline 22 & 0 & 14 & 27 & 39 & 52 & 64 & 70 & 71 \\
\hline 241,242 & 2 & 5 & 13 & 15 & 22 & 27 & 28 & 29 \\
\hline 243,245 & 2 & 6 & 10 & 16 & 22 & 26 & 31 & 35 \\
\hline 246,247 & 1 & 1 & 2 & 2 & 5 & 7 & 7 & 8 \\
\hline 251 & 0 & 3 & 4 & 6 & 7 & 8 & 8 & 9 \\
\hline 252,262 & 0 & 6 & 16 & 32 & 45 & 53 & 68 & 77 \\
\hline 26 & 1 & 7 & 14 & 21 & 29 & 34 & 41 & 46 \\
\hline 27 & 3 & 4 & 7 & 10 & 21 & 26 & 30 & 33 \\
\hline 28 & 1 & 8 & 18 & 43 & 55 & 70 & 85 & 101 \\
\hline 291 & 0 & 1 & 2 & 4 & 5 & 7 & 9 & 10 \\
\hline 292 & 0 & 1 & 2 & 5 & 8 & 10 & 11 & 12 \\
\hline 293 & 0 & 1 & 2 & 2 & 5 & 5 & 5 & 5 \\
\hline 294,295 & 2 & 4 & 9 & 13 & 15 & 17 & 21 & 27 \\
\hline 297 & 0 & 0 & 2 & 3 & 3 & 3 & 4 & 4 \\
\hline 30 & 0 & 3 & 6 & 12 & 14 & 15 & 18 & 21 \\
\hline 31 & 2 & 6 & 10 & 14 & 21 & 29 & 33 & 47 \\
\hline 321 & 0 & 0 & 1 & 3 & 5 & 5 & 7 & 10 \\
\hline 322,323 & 1 & 3 & 3 & 5 & 7 & 8 & 11 & 12 \\
\hline 331,332 & 0 & 1 & 2 & 4 & 4 & 6 & 6 & 9 \\
\hline 334,335 & 0 & 0 & 1 & 2 & 2 & 2 & 3 & 3 \\
\hline 341 & 0 & 0 & 1 & 1 & 1 & 1 & 1 & 1 \\
\hline 343 & 0 & 0 & 0 & 0 & 0 & 0 & 0 & 0 \\
\hline 351 & 0 & 0 & 0 & 1 & 1 & 1 & 1 & 1 \\
\hline 352,354 & 1 & 1 & 2 & 2 & 2 & 2 & 2 & 2 \\
\hline 361,362 & 1 & 5 & 16 & 31 & 43 & 48 & 59 & 74 \\
\hline 363,365 & 1 & 2 & 2 & 3 & 7 & 9 & 9 & 10 \\
\hline 366 & 0 & 1 & 3 & 10 & 15 & 18 & 25 & 30 \\
\hline 40 & 0 & 0 & 3 & 5 & 7 & 7 & 8 & 10 \\
\hline 45 & 2 & 19 & 47 & 91 & 144 & 171 & 202 & 224 \\
\hline 55 & 6 & 7 & 7 & 7 & 7 & 7 & 7 & 7 \\
\hline 642 & 2 & 2 & 2 & 6 & 6 & 6 & 6 & 6 \\
\hline 65,66 & 2 & 7 & 7 & 7 & 7 & 7 & 7 & 7 \\
\hline 92 & 0 & 1 & 2 & 2 & 2 & 2 & 2 & 2 \\
\hline
\end{tabular}

Source: authors' elaboration on the basis of the AMADEUS dataset. See Annex for details on the classification of industries. NACE industries 72 and 73 did not report any multinational investment. 
Table 3. A comparison of productivity estimates in a sample of industries

\begin{tabular}{|c|c|c|c|c|c|}
\hline & NACE2 Industry & Food & Automotive & Wood products & $\begin{array}{c}\text { Rubber and } \\
\text { Plastics }\end{array}$ \\
\hline \multirow[t]{3}{*}{ Lev Pet (2003) } & $\ln$ (labor) & $0.0257 * * *$ & $0.0552 * * *$ & $0.0578 * * *$ & $0.0603 * * *$ \\
\hline & ln (materials) & $0.8436 * * *$ & $0.9756 * * *$ & $0.8547 * * *$ & $0.7672 * * *$ \\
\hline & ln (capital) & $0.0858 * * *$ & $0.1617 * * *$ & $0.0803^{* * *}$ & $0.1021 * * *$ \\
\hline \multirow[t]{8}{*}{ OLS } & $\ln$ (labor) & $0.1494 * * *$ & $0.2184 * * *$ & $0.2653^{* * *}$ & $0.2823 * * *$ \\
\hline & ln (materials) & $0.9199 * * *$ & $0.9224 * * *$ & $0.8992 * * *$ & $0.8927 * * *$ \\
\hline & $\ln$ (capital) & 0.0019 & -0.0238 & 0.0017 & $-0.0261 * * *$ \\
\hline & OLS bias in labor coeff. & + & + & + & + \\
\hline & OLS bias in material coeff. & + & - & - & + \\
\hline & OLS bias in capital coeff. & not sign. & not sign. & not sign. & - \\
\hline & N. of domestic firms & 6880 & 360 & 3172 & 1276 \\
\hline & NACE2 Industry & $\begin{array}{c}\text { Metal } \\
\text { Products }\end{array}$ & Construction & $\begin{array}{c}\text { Hotels and } \\
\text { Restaurants }\end{array}$ & Telecom \\
\hline \multirow[t]{3}{*}{ Lev Pet (2003) } & $\ln$ (labor) & $0.111^{* * *}$ & $0.1270 * * *$ & $0.1995 * * *$ & $0.2124 * * *$ \\
\hline & ln (materials) & $0.8939 * * *$ & $0.7120 * * *$ & $0.7010 * * *$ & $0.8772 * * *$ \\
\hline & $\ln$ (capital) & $0.0831 * *$ & $0.1382 * * *$ & 0.0659 & 0.0049 \\
\hline \multirow[t]{7}{*}{ OLS } & $\ln$ (labor) & $0.3098 * * *$ & $0.3601 * * *$ & $0.3898 * * *$ & $0.5697 * * *$ \\
\hline & ln (materials) & $0.8774 * * *$ & $0.8201 * * *$ & $0.7575 * * *$ & $0.7101 * * *$ \\
\hline & $\ln$ (capital) & $-0.0392 * * *$ & $-0.0097 * *$ & $0.0468 * * *$ & $0.0468 * * *$ \\
\hline & OLS bias in labor coeff. & + & + & + & + \\
\hline & OLS bias in material coeff. & - & + & + & - \\
\hline & OLS bias in capital coeff. & - & - & not sign. & not sign. \\
\hline & N. of domestic firms & 2821 & 8697 & 812 & 721 \\
\hline
\end{tabular}


Table 4. Horizontal spillovers from FDI

(Levinsohn-Petrin semi-parametric estimates of TFP)

\begin{tabular}{|c|c|c|c|c|}
\hline Dependent var. & $\begin{array}{c}\text { Firm-specific } \\
\Delta \ln (\mathrm{TFP})\end{array}$ & $\begin{array}{c}\text { Firm-specific } \\
\Delta \ln (\mathrm{TFP})\end{array}$ & $\begin{array}{l}\text { Industry/region } \\
\text { avg. } \Delta \ln (\mathrm{TFP})\end{array}$ & $\begin{array}{l}\text { Industry/region } \\
\text { avg. } \Delta \ln (\mathrm{TFP})\end{array}$ \\
\hline$H P_{t-1}$ & $\begin{array}{l}.007 \\
(.009)\end{array}$ & - & $\begin{array}{l}.008 \\
(.016)\end{array}$ & - \\
\hline$D_{t-1}$ & - & $\begin{array}{l}.008 \\
(.008)\end{array}$ & - & $\begin{array}{l}.03^{*} \\
(.02)\end{array}$ \\
\hline$D_{t-1} *$ Cumfdi $i_{t-1}$ & - & $\begin{array}{l}-.007^{*} \\
(.004)\end{array}$ & - & $\begin{array}{l}-.014 \\
(.012)\end{array}$ \\
\hline 48 Industry dummies & Yes & Yes & Yes & Yes \\
\hline 8 Regional dummies & Yes & Yes & Yes & Yes \\
\hline 6 Time dummies & Yes & Yes & Yes & Yes \\
\hline R-sq. & .32 & .31 & .26 & .26 \\
\hline N. of obs. & 31068 & 31068 & 1802 & 1802 \\
\hline $\begin{array}{c}\text { Spillover test statistic }{ }^{\text {a }} \\
\qquad X^{2}\end{array}$ & - & 2.00 & & $4.38 * *$ \\
\hline
\end{tabular}

Note: Standard deviation in parentheses.

$*$, ** or ***: significant at the 10,5 or 1 per cent level respectively.

(a) Ho: $\alpha / \beta=0$ given $\alpha D_{t-1}+\beta D_{t-1} * C u m f d i_{t-1}$ 
Table 5. Threshold effects from incremental FDI

Dep var.: Industry/region avg. $\Delta \ln (\mathrm{TFP})$ with Levinsohn-Petrin semi-parametric estimates of productivity)

\begin{tabular}{|c|c|c|c|c|c|}
\hline & (1) & (2) & (3) & (4) & (5) \\
\hline$D_{t-1}$ & $\begin{array}{l}.034^{*} \\
(.02)\end{array}$ & $\begin{array}{c}.035^{* *} \\
(.02)\end{array}$ & $\begin{array}{l}.056^{* * *} \\
(.02)\end{array}$ & $\begin{array}{c}.066^{* * *} \\
(.02)\end{array}$ & $\begin{array}{c}.056 * * \\
(.02)\end{array}$ \\
\hline$D_{t-1} * C u m f d i_{t-1}$ & $\begin{array}{l}-.015 \\
(.01)\end{array}$ & & & & \\
\hline$D_{t-1} * C u m f d i_{t-1} / M E S$ & & $\begin{array}{l}-.25 * \\
(.15)\end{array}$ & $\begin{array}{l}-.26 * \\
(.15)\end{array}$ & $\begin{array}{c}-.29 * * \\
(.14)\end{array}$ & $\begin{array}{c}-.31^{* *} \\
(.15)\end{array}$ \\
\hline$D_{t-1} / M E S$ & & & $\begin{array}{l}-.22 * \\
(.13)\end{array}$ & $\begin{array}{l}-.22 * \\
(.13)\end{array}$ & $\begin{array}{l}-.06 \\
(.17)\end{array}$ \\
\hline Time since $1^{\text {st }}$ FDI & & & & $\begin{array}{c}-.02 * * \\
(.01)\end{array}$ & $\begin{array}{c}-.02 * * \\
(.01)\end{array}$ \\
\hline$S E R V^{*} D_{t-1}$ & & & & & $\begin{array}{l}-.04 \\
(.09)\end{array}$ \\
\hline$S E R V^{*}\left[D_{t-1} * C u m f d i_{t-1} / M E S\right]$ & & & & & $\begin{array}{l}.39 \\
(.59)\end{array}$ \\
\hline$S E R V^{*}\left[D_{t-1} / M E S\right]$ & & & & & $\begin{array}{l}-.29 \\
(.27)\end{array}$ \\
\hline 48 Industry dummies & $83.08^{* * *}$ & $79.85^{* * *}$ & $80.25^{* * *}$ & $84.79 * * *$ & $79.94 * * *$ \\
\hline 8 Regional dummies & 4.63 & 4.50 & 4.58 & 5.65 & 5.51 \\
\hline 6 Time dummies & $46.64 * * *$ & $48.88 * * *$ & $44.67 * * *$ & $47.52 * * *$ & $47.70 * * *$ \\
\hline R-sq. & .26 & .27 & .27 & .27 & .27 \\
\hline N. of obs. & 1802 & 1802 & 1802 & 1802 & 1802 \\
\hline $\begin{array}{l}\text { Modified Durbin-Watson } \\
\text { serial correlation test }\end{array}$ & $\begin{array}{c}1.92 \\
(\rho=0.04)\end{array}$ & $\begin{array}{c}1.92 \\
(\rho=0.04)\end{array}$ & $\begin{array}{c}1.91 \\
(\rho=0.05)\end{array}$ & $\begin{array}{c}1.92 \\
(\rho=0.04)\end{array}$ & $\begin{array}{c}1.92 \\
(\rho=0.04)\end{array}$ \\
\hline $\begin{array}{c}\text { Threshold test statistic }{ }^{\mathrm{a}} \\
X^{2} \\
\text { Intercept test statistic }^{\mathrm{b}} \\
X^{2}\end{array}$ & $4.38 * *$ & $5.80 * *$ & $\begin{array}{c}5.23^{* *} \\
1.62\end{array}$ & $\begin{array}{c}6.15^{* *} \\
1.75\end{array}$ & $\begin{array}{c}5.37 * * \\
0.14\end{array}$ \\
\hline
\end{tabular}

Note: Standard deviation in parentheses. Joint significance tests for industry, region and time dummies.

*, ** or ***: significant at the 10,5 or 1 per cent level respectively.

(a) Ho: $\alpha / \beta=0$ given $\alpha D_{t-1}+\beta D_{t-1} * \operatorname{Cumfdi}_{t-1}$ (Column 1) and $\alpha D_{t-1}+\beta D_{t-1} *$ Cumfdi $i_{t-1} / M E S$ (Columns 2-5)

(b) Ho: $\gamma / \beta=0$ given $\alpha D_{t-1}+\beta D_{t-1} * C u m f d i_{t-1} / M E S+\gamma D_{t-1} / M E S$ 
Table 6. Threshold effects from incremental FDI - Robustness checks

Dep var.: Industry/region avg. $\Delta \ln (\mathrm{TFP})$ with Levinsohn-Petrin semi-parametric estimates of productivity)

\begin{tabular}{|c|c|c|c|c|c|}
\hline & (1) & (2a) & (2b) & (3) & (4) \\
\hline$I N V_{t-1}$ & $\begin{array}{c}.060^{* *} \\
(.02)\end{array}$ & & & & \\
\hline$I N V_{t-1} * C u m f d i_{t-1} / M E S$ & $\begin{array}{l}-.28 * * \\
(.12)\end{array}$ & & & & \\
\hline$I N V_{t-1} / M E S$ & $\begin{array}{l}-.16 \\
(.12)\end{array}$ & & & & \\
\hline$D_{t-1}$ & & $\begin{array}{c}.066^{* * *} \\
(.02)\end{array}$ & $\begin{array}{c}.066^{* * *} \\
(.02)\end{array}$ & $\begin{array}{c}.068^{* * *} \\
(.02)\end{array}$ & $\begin{array}{c}.040 * * \\
(.02)\end{array}$ \\
\hline$D_{t-1} * C u m f d i_{t-1} / M E S$ & & $\begin{array}{l}-.28^{*} \\
(.15)\end{array}$ & $\begin{array}{l}-.29 * \\
(.15)\end{array}$ & $\begin{array}{l}-.28 * \\
(.15)\end{array}$ & $\begin{array}{l}-.19 * \\
(.12)\end{array}$ \\
\hline$D_{t-1} / M E S$ & & $\begin{array}{l}-.22 * \\
(.13)\end{array}$ & $\begin{array}{l}-.22 * \\
(.13)\end{array}$ & $\begin{array}{l}-.25^{*} \\
(.13)\end{array}$ & $\begin{array}{l}-.11 \\
(.11)\end{array}$ \\
\hline Time since $1^{\text {st }} F D I$ & $\begin{array}{c}-.02 * * \\
(.01)\end{array}$ & $\begin{array}{c}-.02 * * \\
(.01)\end{array}$ & $\begin{array}{c}-.02 * * \\
(.01)\end{array}$ & $\begin{array}{c}-.02 * * \\
(.01)\end{array}$ & $\begin{array}{l}-.01 \\
(.01)\end{array}$ \\
\hline Herfindal (all firms) & & $\begin{array}{l}-.004 \\
(.03)\end{array}$ & & $\begin{array}{l}-.005 \\
(.03)\end{array}$ & \\
\hline Herfindal (dom. firms) & & & $\begin{array}{l}.006 \\
(.03)\end{array}$ & & \\
\hline FDI Stock 1994 & & & & $\begin{array}{l}.018 \\
(.02)\end{array}$ & \\
\hline Absorptive capacity & & & & $\begin{array}{l}.17^{*} \\
(.09)\end{array}$ & \\
\hline 48 Sector dummies & $85.16^{* * *}$ & $84.31^{* * *}$ & $84.91^{* * *}$ & $83.73^{* * *}$ & $217.1^{* * *}$ \\
\hline 8 Regional dummies & 5.27 & 5.62 & 5.65 & 6.46 & 6.17 \\
\hline 6 Time dummies & $47.49 * * *$ & $46.32 * * *$ & $47.35^{* * *}$ & $45.44^{* * *}$ & $71.98^{* * *}$ \\
\hline R-sq. & .27 & .27 & .28 & .30 & .52 \\
\hline N. of obs. & 1802 & 1802 & 1802 & 1802 & 1792 \\
\hline $\begin{array}{c}\text { Modified Durbin-Watson } \\
\text { serial correlation test }\end{array}$ & $\begin{array}{c}1.92 \\
(\rho=0.04)\end{array}$ & $\begin{array}{c}1.92 \\
(\rho=0.05)\end{array}$ & $\begin{array}{c}1.92 \\
(\rho=0.05)\end{array}$ & $\begin{array}{c}1.92 \\
(\rho=0.04)\end{array}$ & $\begin{array}{c}2.06 \\
(\rho=-0.02)\end{array}$ \\
\hline $\begin{array}{c}\text { Threshold test }^{\mathrm{a}} \\
X^{2} \\
\text { Intercept test statistic }^{\mathrm{b}} \\
X^{2} \\
\end{array}$ & $\begin{array}{c}16.18^{* * *} \\
1.88\end{array}$ & $6.06^{* *}$ & $6.18^{* *}$ & $5.81 * *$ & $4.18^{* *}$ \\
\hline
\end{tabular}

Note: Standard deviation in parentheses. Joint significance tests for sector, region and time dummies.

$*, * *$ or $* * *$ : significant at the 10,5 or 1 per cent level respectively.

Column (4): Modified Levinsohn-Petrin semi-parametric TFP estimates augmented with regional fixed-effects

(a) Ho: $\alpha / \beta=0$ given $\alpha I N V_{t-1}+\beta \operatorname{INV}_{t-1} * \operatorname{Cumfdi}_{t-1} / M E S$ (Column 1) and $\alpha D_{t-1}+\beta D_{t-1} * C_{u m f d i} / M E S$ (Columns 2-5)

(b) Ho: $\gamma / \beta=0$ given $\alpha I N V_{t-1}+\beta I N V_{t-1} * \operatorname{Cumfdi}_{t-1} / M E S+\gamma I N V_{t-1} / M E S$ (Column 1) and $\alpha D_{t-1}+\beta D_{t-1} * C_{\text {Cumfdi }} / \mathrm{MES}+\gamma D_{t-1} / \mathrm{MES}$ (Columns 2-5) 
Table 7. Industry-specific FDI thresholds for positive spillovers in the average region

\begin{tabular}{|c|c|c|c|c|c|}
\hline Nace & CumFDI* & Nace & CumFDI* & Industry Type & CumFDI* \\
\hline 10,14 & 1 & 292 & 4 & Economies of Scale & 25 \\
\hline 151,152 & 2 & 293 & 4 & Traditional & 3 \\
\hline 153,155 & 2 & 294,295 & 5 & Specialized & 13 \\
\hline 156 & 2 & 297 & 2 & High Tech & 9 \\
\hline 157 & 9 & 30 & 3 & Services & - \\
\hline 158 & 2 & 31 & 31 & & \\
\hline 159 & 3 & 321 & 14 & & \\
\hline 16 & 3 & 322,323 & 89 & & \\
\hline 17 & 3 & 331,332 & 104 & & \\
\hline 18 & 3 & 334,335 & 23 & & \\
\hline 19 & 3 & 341 & 2 & & \\
\hline 20 & 2 & 343 & 2 & & \\
\hline 21 & 2 & 351 & 93 & & \\
\hline 22 & 2 & 352,354 & 39 & & \\
\hline 241,242 & 3 & 361,362 & 2 & & \\
\hline 243,245 & 56 & 363,365 & 4 & & \\
\hline 246,247 & 21 & 366 & 3 & & \\
\hline 251 & 18 & 40 & 3 & & \\
\hline 252,262 & 2 & 45 & 1 & & \\
\hline 26 & 3 & 55 & - & & \\
\hline 27 & 14 & 642 & - & & \\
\hline 28 & 2 & 65,66 & - & & \\
\hline 291 & 2 & 92 & - & & \\
\hline
\end{tabular}

Note: CumFDI* $=-\alpha * \mathrm{MES} / \beta-\gamma / \beta$ as retrieved from Column 5 , Table 5 . The threshold for services CumFDI ${ }^{*}=$ $\left(\alpha+\alpha_{S}\right) * \operatorname{MES} /\left(\beta+\beta_{S}\right)-\left(\gamma+\gamma_{S}\right) /\left(\beta+\beta_{S}\right)$ as retrieved from Column 5 , Table 5 , turns out to be negative.

See the Statistical Annex for the definition of the NACE codes and industry classification. 


\section{Statistical Annex - Classification of industries}

The model includes a total of 48 NACE 2 and 3 digits industries, grouped as follows:

Economies of scale industries: 10-11-12-13 and 14 (mining of coal, metals and stone; extraction of petroleum and natural gas); 21 (paper and pulp); 22 (publishing and press); 241 and 242 (basic chemicals and agrochemicals); 246 and 247 (other chemical products and synthetic fibres); 251 (rubber products); 26 (other nonmetallic products); 27 (metallurgy); 297 (domestic appliances); 31 (electrical appliances, excluding domestic); 321 (electronics); 322 and 323 (communication equipment); 341 (car production); 343 (car components); 351 (ship building); 352 and 354 (railways; motorcycles); 40 (energy);

Traditional industries: 151 and 152 (production and transformation of meat and fish); 153 and 155 (vegetables, milk and dairy products); 156 (grains); 157 (pet food); 158 (fabrication of bread, tea, coffee); 159 (drink and beverages); 16 (tobacco); 17 (textiles); 18 (clothing); 19 (leather); 20 (wood); 28 (metals); 361 and 362 (furniture); 363 and 365 (musical instruments and toys); 366 (other general manufacturing);

Specialized industries; 252 and 262 (plastic products); 291 (mechanical machinery); 292 (general machinery); 293 (agricultural machines); 294 and 295 (machine tools); 334 and 335 (optics, photography, clocks); 45 (construction)

High-tech industries: 243 and 245 (paintings and pharmaceuticals); 244 (pharmaceuticals); 30 (office machines and computers); 331 and 332 (medical and precision instruments); 642 (telecommunication)

Services: 55 (hotels and restaurants); 65 and 66 (financial intermediation and insurance); 72 (computer and related activities); 73 (research and development); 92 (cultural and sporting activities) 


\section{Appendix: Data sources and issues}

Balance sheet data of domestic firms as well as information on the presence of MNEs have been retrieved by the AMADEUS dataset, commercially available from the Bureau Van Dijck (www.bvdep.com). The latter is a comprehensive, pan-European database developed by a consulting firm, Bureau van Dijck. It contains balance sheet data in time series on 7 million public and private companies in 38 European countries (2004 edition). The dataset comes as a modular product: a version including the top 250,000 companies, the top 1.5 million (employed in this paper) or all 7 million companies in the considered countries. When using these data, three issues are worth pointing out:

1. The available datasets tend to exclude small firms (mainly domestic) from the records, and thus yield a lower proportion of domestic firms vs. multinationals with respect to the Romanian population of firms. The latter issue does not necessarily distort our spillover measure, since while it is true that smaller firms could be characterized, in principle, by a lower absorptive capacity of technological spillovers, they also tend to grow faster in terms of productivity. Since we use TFP changes as our control variable, the latter entails a conservative measure of productivity.

2. In AMADEUS the information on ownership is recorded only for the last available year (2000 or 2001), thus implying that some of the firms that we consider as foreign in 2001 might have been domestic in the years before. In order to gauge the magnitude of this issue, we have compared different yearly releases of AMADEUS, finding that, given a MNE in year 2000 or 2001, there is a 15 per cent chance that the same firm is a domestic one before that year, while the probability of the opposite event (a firm switching from MNE to domestic) is negligible. The issue is however not critical for our exercise, since the aim is to test the impact of the entry of MNEs on the average productivity of a sample of domestic firms. If we incorrectly attribute the multinational status to that 15 per cent of firms which sometime before 2001 were still domestic, we de facto exclude them from our dependent variable (domestic firms' TFP). The latter exclusion leads to a more conservative TFP measure, if we assume that MNEs acquire the most productive domestic firms (Arnold and Javorcik, 2005). Moreover, considering as MNEs some firms which for a certain number of years have remained domestic would lead to a more modest spillover effect, as we expect domestic entry to have a lower impact on domestic productivity than foreign entry. Thus, if anything, these potential measurement errors would lead to a more conservative assessment of the spillover effect.

3. In terms of entry and exit dynamics of both domestic and foreign firms, the entry rate retrieved from our sample (see Table 1) matches very closely the official entry rate recorded by the Romanian Chamber of Commerce in the considered period. The lower exit rate reported in our sample is likely due to the large-firm bias of the dataset, since in transition economies larger firms on average tend to benefit from softer budget constraints and display higher survival rates than small firms. Again, the latter issue does not affect our exercise: if soft budget constraints play a role, then our TFP is measured conservatively, because the selection effect driving out inefficient domestic firms works less intensively. 


\section{Publications in the Report Series Research* in Management}

\section{ERIM Research Program: "Strategy and Entrepreneurship"}

2009

Domestic Plant Productivity and Incremental Spillovers from Foreign Direct Investment

Carlo Altomonte and Enrico Pennings

ERS-2009-012-STR

http://hdl.handle.net/1765/15143

Boards of Directors' Contribution to Strategy: A Literature Review and Research Agenda

Amedeo Pugliese, Pieter-Jan Bezemer, Alessandro Zattoni, Morten Huse, Frans A.J. Van den Bosch, and Henk W. Volberda ERS-2009-013-STR

http://hdl.handle.net/1765/15144

* A complete overview of the ERIM Report Series Research in Management: https://ep.eur.nl/handle/1765/1

ERIM Research Programs:

LIS Business Processes, Logistics and Information Systems

ORG Organizing for Performance

MKT Marketing

F\&A Finance and Accounting

STR Strategy and Entrepreneurship 